\title{
Design, synthesis and characterization of $1 H$-pyridin-4-yl-3,5- disubstituted indazoles and their AKT inhibition activity
}

\author{
SURENDRAREDDY GOGIREDDY ${ }^{\mathrm{a}}$, ARUNASREE M KALLE ${ }^{\mathrm{b}}, \mathrm{P} \mathrm{K} \mathrm{DUBEY}^{\mathrm{c}}$ and \\ ARAVA VEERA REDDY ${ }^{\mathrm{a}, *}$ \\ ${ }^{a}$ R\&D Centre, Suven Life Sciences Ltd., Plot No. \#18, Phase-III, Jeedimetla, Hyderabad 500 055, India \\ ${ }^{b}$ Department of Animal Sciences, School of Life Sciences, University of Hyderabad, Hyderabad 500 046, India \\ ${ }^{c}$ Department of Chemistry, J N T University, Hyderabad 500 072, India \\ e-mail: reddyvenis@rediffmail.com
}

MS received 14 October 2013; revised 14 February 2014; accepted 19 February 2014

\begin{abstract}
A new series of 1H-pyridin-4-yl-3,5-disubstituted indazoles and their derivatives were synthesized by the reaction of 5-Bromo-1-(2-cyano-pyridin-4-yl)- $1 H$-indazole-3-carboxylic acid diethylamide with aryl boronic acids by Suzuki coupling reaction in the presence of $\mathrm{Pd}(\mathrm{OAc})_{2}$ and $\mathrm{CsF}$. All the new compounds have been characterized by spectral data. The title compounds were subsequently evaluated for their Akt kinase activity.
\end{abstract}

Keywords. $1 H$-pyridin-4-yl-3,5-disubstituted indazoles; Suzuki reaction; Akt kinase activity.

\section{Introduction}

In organic synthesis, Palladium-catalysed new carboncarbon bond formation from aryl halides with organo boronic acids via Suzuki coupling reaction has been proved to be an important method. The 2010 Nobel Prize in chemistry was awarded jointly to Ei-ichi Negishi, Akira Suzuki and Richard F. Heck for developing new methods for connecting carbon atoms together, which are key steps in building complex and bioactive molecules. However, the Suzuki reaction provides a reliable method for the preparation of biaryl derivatives. ${ }^{1}$ Recently, Migliorini et al. ${ }^{2}$ reported the application of the Suzuki reaction to synthesis of novel 5 -substituted pyrrole and thiophenyl indazole in good yields.

Indazole and pyridine are highly utilized moieties and are found in active compounds having proportion such as male contraception, anti-cancer, ${ }^{3}$ anti-viral, ${ }^{4}$ cytotoxic $^{5}$ and Akt inhibition ${ }^{6}$ (figure 1). In regulating cellular growth and survival, the kinase Akt is a key signalling node and is an important target for drug development. The first indazole-based scaffold was reported by Abott Group ${ }^{6}$ (figure 1). Indazole derivatives bearing aryl or $O$-aryl groups on the 5 position have been prepared and identified as potent, kinase inhibitors ${ }^{7}$ selective glucocorticoid receptor agonists, antagonists ${ }^{8}$ and

*For correspondence as anti-cancer compounds. ${ }^{9}$ Also 2,4-disubstituted pyridine derivatives play a vital role in biological activity, especially mono methyl amide function activity at 2 position, prepared and identified as biologically active anti-cancer ${ }^{10}$ compounds. As part of our ongoing research on indazoles ${ }^{11}$ and pyridines, ${ }^{12}$ we were interested in coupling the two moieties and incorporating the different aryl groups on 5 position of indazole ring through Suzuki coupling and conversion of $-\mathrm{CN}$ to mono methyl amide at 2 position of pyridine ring. Thus, by incorporating aryl groups on 5 position and mono methyl amide function at 2 position may lead to synthesis of more significant Akt inhibitors than the existing ones (figure 2).

\section{Experimental}

\subsection{General information}

All reagents were obtained commercially and were of the highest commercial quality and used without further purification. Solvents were freshly distilled and used. Melting points were determined in open capillaries and are uncorrected. TLC or HPLC routinely checked for the purity of all compounds. IR spectra were recorded on a Perkin-Elmer model 2000 instrument in $\mathrm{KBr}$ phase. ${ }^{1} \mathrm{H}-\mathrm{NMR}(400 \mathrm{MHz})$ and ${ }^{13} \mathrm{C}-\mathrm{NMR}(100 \mathrm{MHz})$ spectra were recorded in $\mathrm{CDCl}_{3}$ or DMSO using Bruker instrument and mass spectra were recorded on a PerkinElmer mass spectrometer operating at $70 \mathrm{eV}$. 
<smiles>Cc1n[nH]c2ccc(-c3cncc(OCC(N)Cc4c[nH]c5ccccc45)c3)cc12</smiles><smiles>Cc1n[nH]c2ccc(-c3cncc(OCC(N)Cc4ccccc4)c3)cc12</smiles>

$3\left(\mathrm{IC}_{50}=11 \mathrm{nM}\right)$<smiles>NC(COc1cncc(-c2ccc3[nH]ncc3c2)c1)Cc1c[nH]c2ccccc12</smiles>

$2(\mathrm{Ki}=0.99 \mathrm{nM})$<smiles></smiles>

$4 \quad\left(\mathrm{IC}_{50}=1.7 \mu \mathrm{M}\right)$

Figure 1. Indazole and pyridine scaffold cytotoxic and Akt inhibitors.

\subsection{Synthesis by Suzuki reaction}

General procedure for the preparation of 5arylsubstituted-1-(2-cyanopyridin-4-yl)-N,N-diethyl1 H-indazole-3-carboxamide 7(a).

Method A: To a solution of 5-bromo-1-(2-cyanopyridin-4-yl)- $1 H$-indazole-3-carboxylic acid diethylamide 5 (5 g, $0.0125 \mathrm{~mol}$ ), 4-methoxyphenylboronic acid $6 \mathbf{a}(3.8 \mathrm{~g}, 0.025 \mathrm{~mol})$ in DMF $(90 \mathrm{~mL})$, palladium acetate $(0.56 \mathrm{~g}, 0.0025 \mathrm{~mol})$, cesium fluoride $(3.8 \mathrm{~g}$, $0.025 \mathrm{~mol})$ and water $(10 \mathrm{~mL})$ were added at room temperature. Reaction mass was heated to $100^{\circ} \mathrm{C}$ and maintained for $2 \mathrm{~h}$ at $95-100^{\circ} \mathrm{C}$. Upon completion of reaction, the reaction mass was quenched into ice water $(200 \mathrm{~mL})$ and dichloromethane $(200 \mathrm{~mL})$. The organic layer was separated and dried over $\mathrm{Na}_{2} \mathrm{SO}_{4}$ and distilled off the solvent to get the crude product, which was purified by column chromatography.
Method B: To a solution of 5-bromo-1-(2-cyanopyridin-4-yl)- $1 H$-indazole-3-arboxylic acid diethylamide 5 (0.5 g, $0.0012 \mathrm{~mol})$, 4-isobutylphenylboronic acid 6e $(0.447 \mathrm{~g}, 0.0025 \mathrm{~mol})$ in DMF $(5 \mathrm{~mL})$, tetrakis (triphenylphosphine)palladium(0) $(0.2 \mathrm{~g}, 0.00017 \mathrm{~mol})$, sodium carbonate $(0.254 \mathrm{~g}, 0.0023 \mathrm{~mol})$ and water $(0.75 \mathrm{~mL})$ were added at room temperature. Reaction mass was heated to $100^{\circ} \mathrm{C}$ and maintained for $12-14 \mathrm{~h}$ at $95-100^{\circ} \mathrm{C}$. Upon completion of reaction, the reaction mass was quenched into ice water $(200 \mathrm{~mL})$ and dichloromethane $(200 \mathrm{~mL})$. The organic layer was separated and dried over $\mathrm{Na}_{2} \mathrm{SO}_{4}$ and distilled off the solvent to get the crude product, which was purified by column chromatography.

Method C: To a solution of 5-bromo-1-(2-cyanopyridin-4-yl)- $1 H$-indazole-3-arboxylic acid diethylamide 5 (0.2 g, $0.0005 \mathrm{~mol})$, 4-isobutylphenylboronic acid 6e (0.178 g, $0.001 \mathrm{~mol})$ in DMF (3 mL), dppf.PdCl $\mathrm{Al}_{2}$

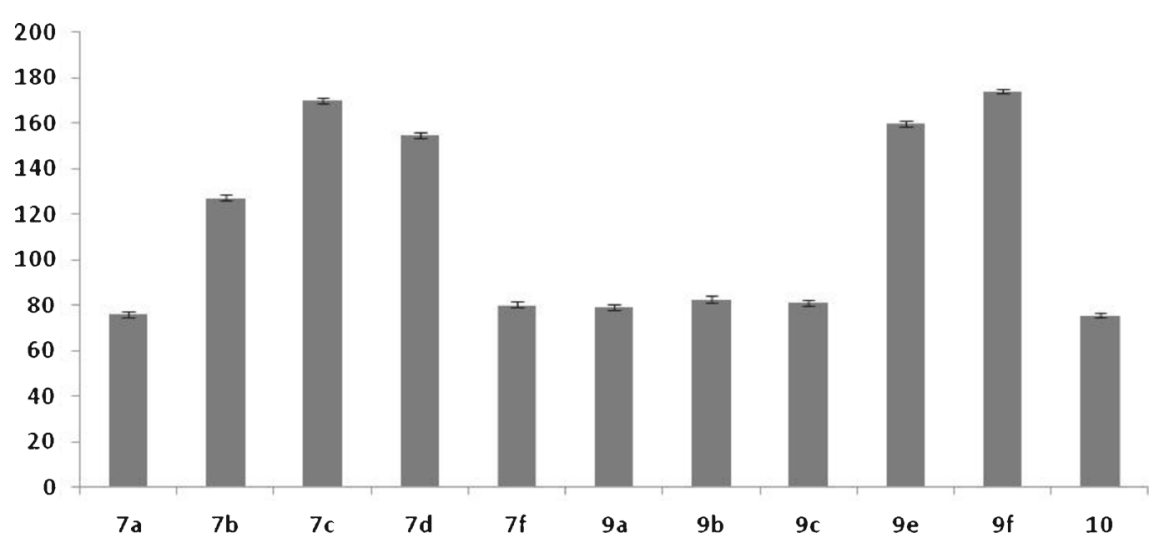

Figure 2. Graph showing $\%$ activity of AKT kinase. 
(0.08 g, $0.0001 \mathrm{~mol})$, sodium carbonate $(0.106 \mathrm{~g}$, $0.001 \mathrm{~mol})$ and water $(0.4 \mathrm{~mL})$ were added at room temperature. Reaction mass was heated to $100^{\circ} \mathrm{C}$ and maintained for $13-15 \mathrm{~h}$ at $95-100^{\circ} \mathrm{C}$. Only $50-60 \%$ conversion was observed. Reaction mass was quenched into ice water $(15 \mathrm{~mL})$ and dichloromethane $(30 \mathrm{~mL})$. The organic layer was separated and dried over $\mathrm{Na}_{2} \mathrm{SO}_{4}$ and distilled off the solvent to get the crude product, which was purified by column chromatography.

\section{2a 1-(2-cyanopyridin-4-yl)- $N, N$-diethyl-5-(4-metho-} xyphenyl)-1H-indazole-3-carboxamide (7a): Yield (77.36\% ); mp 117-120 ${ }^{\circ} \mathrm{C}$; IR ( $\left.\mathrm{KBr}\right): 1607.74(-\mathrm{C}=\mathrm{O})$, $2238.49(-\mathrm{CN})\left(\mathrm{cm}^{-1}\right) ;{ }^{1} \mathrm{H}$ NMR $\left(400 \mathrm{MHz}, \mathrm{CDCl}_{3}\right): \delta$ $1.32-1.37(\mathrm{~m}, 6 \mathrm{H}), 3.64-3.82(\mathrm{qd}, 4 \mathrm{H}), 3.84(\mathrm{~s}, 3 \mathrm{H})$, $6.94(\mathrm{~d}, 2 \mathrm{H}, J=8.55 \mathrm{~Hz}), 7.54(\mathrm{~d}, 2 \mathrm{H}, J=8.56 \mathrm{~Hz})$, $7.73(\mathrm{~d}, 1 \mathrm{H}, J=8.71 \mathrm{~Hz}), 7.85(\mathrm{~d}, 1 \mathrm{H}, J=8.80 \mathrm{~Hz})$, $7.96\left(\mathrm{dd}, 1 \mathrm{H}, J_{1}=1.68, J_{2}=5.50 \mathrm{~Hz}\right), 8.16(\mathrm{~d}, 1 \mathrm{H}$, $J=1.29 \mathrm{~Hz}), 8.31(\mathrm{~s}, 1 \mathrm{H}), 8.77(\mathrm{~d}, 1 \mathrm{H}, J=5.52 \mathrm{~Hz})$; ${ }^{13} \mathrm{C}$ NMR $\left(100 \mathrm{MHz}, \mathrm{CDCl}_{3}\right): \delta 12.83,14.76$, $40.93,43.42,55.27,110.78,114.23,116.71,116.82$, $119.24,120.66,127.15,128.28,128.61,132.21$, $135.14,137.29,137.73,144.08,147.36,152.29$, 159.31, 161.94; ms: m/z $426.2(\mathrm{M})^{+}$. Anal. Calcd. for $\mathrm{C}_{25} \mathrm{H}_{23} \mathrm{~N}_{5} \mathrm{O}_{2}$ : C, 70.57; H, 5.45; N, 16.46. Found. C, 70.56; H, 5.41; N, 16.48 .

\subsection{General procedure for the preparation of 5-arylsubstituted-methyl 4-(3-diethylcarbamoyl)- 1H-indazol-1-yl)picolinate (8a)}

To a solution of 1-(2-cyanopyridin-4-yl)- $N, N$-diethyl5-(4-methoxyphenyl)-1 $H$-indazole-3-carboxamide7a (1.6 g, $0.0037 \mathrm{~mol})$ in methanol $(40 \mathrm{~mL})$, thionyl chloride was added at $30-40^{\circ} \mathrm{C}$ over a period of $15-20 \mathrm{~min}$. Reaction mass was heated to $60-64^{\circ} \mathrm{C}$ and maintained for $12 \mathrm{~h}$. Upon completion of reaction, the solvent was distilled off under vacuum at $50^{\circ} \mathrm{C}$ to get the crude. To the crude, water $(5 \mathrm{~mL})$ and ethyl acetate $(15 \mathrm{~mL})$ were added and stirred for $30 \mathrm{~min}$ at room temperature. The organic layer was separated and washed with brine solution $(2 \mathrm{~mL})$. Organic solvent was distilled off to get the solid.

2.3a Methyl 4-(3-(diethylcarbamoyl)-5-(4-methoxyphenyl)-1H-indazol-1-yl)picolinate (8a): Yield (88\%); mp 138-142 ${ }^{\circ} \mathrm{C}$; IR (KBr): $1727.33(-\mathrm{C}=\mathrm{O})\left(\mathrm{cm}^{-1}\right) ;{ }^{1} \mathrm{H}$ NMR $\left(400 \mathrm{MHz}, \mathrm{CDCl}_{3}\right): \delta 1.33-1.41\left(\mathrm{td}, 6 \mathrm{H}, J_{1}=\right.$ $\left.7.14, J_{2}=7.01 \mathrm{~Hz}\right), 3.65(\mathrm{q}, 2 \mathrm{H}), 3.79(\mathrm{q}, 2 \mathrm{H}), 3.87$ (s, 3H), 4.08 (s, 3H), 6.99 (d, 2H, $J=8.52 \mathrm{~Hz}), 7.06$ $(\mathrm{d}, 2 \mathrm{H}, J=8.52 \mathrm{~Hz}), 7.79\left(\mathrm{dd}, 1 \mathrm{H}, J_{1}=8.68, J_{2}=\right.$ $1.12 \mathrm{~Hz}), 7.97(\mathrm{~m}, 2 \mathrm{H}), 8.39(\mathrm{~s}, 1 \mathrm{H}), 8.65(\mathrm{~d}, 1 \mathrm{H}$,
$J=1.76 \mathrm{~Hz}), 8.86(\mathrm{~d}, 1 \mathrm{H}, J=5.32 \mathrm{~Hz}) ;{ }^{13} \mathrm{C} \mathrm{NMR}$ $\left(100 \mathrm{MHz}, \mathrm{CDCl}_{3}\right): \delta$ 12.85, 14.72, 40.96, 43.47, $53.15,55.28,110.86,114.21,115.99,117.53,120.73$, $127.08,128.40,132.65,137.09,137.99,143.42$, $147.80,149.56,151.18,159.24,162.24,165.21$; ms: $\mathrm{m} / \mathrm{z} 459.2(\mathrm{M})^{+}$.

\subsection{General procedure for the preparation}

of 5-arylsubstituted-N, N-diethyl-1-(2-

(methylcarbamoyl)pyridin-4-yl)-1H-indazole-3carboxamides $\mathbf{9}(\boldsymbol{a})$

Method A: To a solution of methyl 4-(3-(diethylcarbamoyl)-5-(4-methoxyphenyl)- $1 H$-indazol-1-yl)picolinate 8a (1.3 g, $0.0028 \mathrm{~mol})$ in methanol, mono methylamine gas was bubbled into reaction mass at $25-40^{\circ} \mathrm{C}$ and maintained for $30 \mathrm{~min}$. Upon completion of reaction, the solvent was distilled off to get the crude. To the crude, water $(5 \mathrm{~mL})$ and ethyl acetate $(20 \mathrm{~mL})$ were added and stirred for $30 \mathrm{~min}$. The organic layer was separated and washed with brine solute $(2 \mathrm{~mL})$. The organic layer was dried over $\mathrm{Na}_{2} \mathrm{SO}_{4}$ and distilled off the solvent to get solid, which was slurred in hexane $(5 \mathrm{~mL})$ and filtered and washed with hexane $(5 \mathrm{~mL})$.

Method B: To a solution of 5-bromo- $N, N$-diethyl1-(2-(methylcarbamoyl)pyridin-4-yl)- $1 H$-indazole-3carboxamide 11 (0.55 g, $0.00116 \mathrm{~mol})$, 4-methoxyphenylboronic acid 6a $(0.35 \mathrm{~g}, 0.0023 \mathrm{~mol})$ in DMF $(5 \mathrm{~mL})$, palladium acetate $(0.05 \mathrm{~g}, 0.00022 \mathrm{~mol})$, cesium fluoride $(3.8 \mathrm{~g}, 0.0025 \mathrm{~mol})$ and water $(0.75 \mathrm{~mL})$ were added at room temperature. Reaction mass was heated to $100^{\circ} \mathrm{C}$ and maintained for $12 \mathrm{~h}$ at $95-100^{\circ} \mathrm{C}$. Reaction was not completed $(60-70 \%$ completed). The mass was quenched into ice water $(15 \mathrm{~mL})$ and dichloromethane $(30 \mathrm{~mL})$ at $15-20^{\circ} \mathrm{C}$. The organic layer was separated and dried over $\mathrm{Na}_{2} \mathrm{SO}_{4}$ and distilled off the organic solvent to get the crude product, which was purified by column chromatography.

2.4a N,N-diethyl-5-(4-methoxyphenyl)-1-(2-(methylcarbamoyl)pyridin-4-yl)-1H-indazole-3-carboxamide (9a): Yield (74\%); mp $142-144^{\circ} \mathrm{C}$; IR (KBr): $1682.96(-\mathrm{C}=\mathrm{O}), 3374.61\left(-\mathrm{NHCH}_{3}\right)\left(\mathrm{cm}^{-1}\right) ;{ }^{1} \mathrm{H}-\mathrm{NMR}$ $\left(400 \mathrm{MHz}, \mathrm{CDCl}_{3}\right): \delta 1.32-1.41\left(\mathrm{td}, 6 \mathrm{H}, J_{1}=6.94\right.$, $\left.J_{2}=7.06, \mathrm{~Hz}\right), 3.09(\mathrm{~d}, 3 \mathrm{H}, J=5.04 \mathrm{~Hz}), 3.65(\mathrm{q}, 2 \mathrm{H})$, 3.79 (q, 2H), 3.86 (s, 3H), 6.98 (d, 2H, $J=8.58 \mathrm{~Hz})$, $7.61(\mathrm{~d}, 2 \mathrm{H}, J=8.58 \mathrm{~Hz}), 7.76\left(\mathrm{dd}, 1 \mathrm{H}, J_{1}=8.76\right.$, $\left.J_{2}=1.02 \mathrm{~Hz}\right), 7.91\left(\mathrm{dd}, 1 \mathrm{H}, J_{1}=5.34, J_{2}=1.96 \mathrm{~Hz}\right)$, $8.01(\mathrm{~d}, 1 \mathrm{H}, J=8.84 \mathrm{~Hz}), 8.09(\mathrm{q}, 1 \mathrm{H}), 8.39(\mathrm{~s}, 1 \mathrm{H})$, $8.65(\mathrm{~d}, 1 \mathrm{H}, J=5.35 \mathrm{~Hz}), 8.70(\mathrm{~d}, 1 \mathrm{H}, J=1.52 \mathrm{~Hz})$; ${ }^{13} \mathrm{C}-\mathrm{NMR}\left(100 \mathrm{MHz}, \mathrm{CDCl}_{3}\right): \delta 12.85,14.74,26.14$, $40.95,43.48,55.27,111.15,112.73,114.18,116.94$, 
$120.60,127.02,128.30,128.41,132.75,136.95$, $138.07,143.17,148.07,149.53,151.77,159.18$, 162.34, 164.22; ms: m/z 458.2 (M) ${ }^{+}$. Anal .Calcd. for $\mathrm{C}_{26} \mathrm{H}_{27} \mathrm{~N}_{5} \mathrm{O}_{3}$ : C, 68.25; H, 5.95; N, 15.31. Found $\mathrm{C}$, $68.20 ; \mathrm{H}, 5.92 ; \mathrm{N}, 15.30$.

\subsection{Preparation of methyl 4-(5-bromo-3- (diethylcarbamoyl)-1H-indazol-1-yl) picolinate 10}

To a solution of 5-bromo-1-(2-cyanopyridin-4-yl)- $1 H$ indazole-3-carboxamide 5 (4 g, $0.010 \mathrm{~mol})$ in methanol, thionyl chloride $(7.1 \mathrm{~g}, 0.060 \mathrm{~mol})$ was added at $25-40^{\circ} \mathrm{C}$ over a period of $15 \mathrm{~min}$. Reaction mass was heated to $64^{\circ} \mathrm{C}$ and maintained for $24 \mathrm{~h}$. After completion of reaction, the solvent was distilled off the solvent to get the crude product. To the crude product water $(20 \mathrm{~mL})$ and ethyl acetate $(50 \mathrm{~mL})$ were added and stirred for $20 \mathrm{~min}$. The organic layer is separated and washed with brine solution $(5 \mathrm{~mL})$. The organic layer is dried over $\mathrm{Na}_{2} \mathrm{SO}_{4}$ and distilled off the solvent to get the desired product, which is slurred in hexane and filtered at room temperature.

Yield (71.75\%); mp 153-155 ${ }^{\circ} \mathrm{C}$; IR (KBr): 1743.72 $(-\mathrm{C}=\mathrm{O})\left(\mathrm{cm}^{-1}\right) ;{ }^{1} \mathrm{H}-\mathrm{NMR}\left(400 \mathrm{MHz}, \mathrm{CDCl}_{3}\right): \delta(\mathrm{td}$, $\left.6 \mathrm{H}, J_{1}=7.06, J_{2}=6.95 \mathrm{~Hz}\right), 3.63(\mathrm{q}, 2 \mathrm{H}), 3.79$ $(\mathrm{q}, 2 \mathrm{H}), 4.10(\mathrm{~s}, 3 \mathrm{H}), 7.65\left(\mathrm{dd}, 1 \mathrm{H}, J_{1}=8.98, J_{2}=\right.$ $1.72 \mathrm{~Hz}), 7.80(\mathrm{~d}, 1 \mathrm{H}, J=8.96 \mathrm{~Hz}), 7.92(\mathrm{dd}, 1 \mathrm{H}$, $\left.J_{1}=5.12, J_{2}=2.0 \mathrm{~Hz}\right), 8.47(\mathrm{~d}, 1 \mathrm{H}, J=1.12 \mathrm{~Hz})$, $8.58(\mathrm{~d}, 1 \mathrm{H}, J=1.89 \mathrm{~Hz}), 8.88(\mathrm{~d}, 1 \mathrm{H}, J=5.41 \mathrm{~Hz})$; ${ }^{13} \mathrm{C}-\mathrm{NMR}\left(100 \mathrm{MHz}, \mathrm{CDCl}_{3}\right): \delta 12.75,14.66,41.12$, $43.41,53.17,111.78,116.17,117.20,117.75,126.29$, $127.93,131.90,137.63,142.37,147.40,149.68$, 151.27, 161.53, 165.02; ms: m/z $431.1(\mathrm{M})^{+}, 431.2$ $(\mathrm{M})^{+2}, 433.9(\mathrm{M})^{+3}$. Anal Calcd. for $\mathrm{C}_{19} \mathrm{H}_{19} \mathrm{BrN}_{4} \mathrm{O}_{2}$ : C, 52.91; H, 4.44; N, 12.99; Found C, 52.90; H, 4.45; N, 12.98 .

\subsection{Preparation of 5-bromo- $N, N$-diethyl-1-(2-} (methylcarbamoyl)pyridin-4-yl)-1H-indazole-3carboxamide (11)

To a solution of methyl 4-(5-bromo-3-(diethylcarbamoyl)- $1 H$-indazol-1-yl) picolinate $\mathbf{1 0}$ (3 g, 0.0069) in methanol $(50 \mathrm{~mL})$, mono methylamine gas was bubbled into reaction mass at $25-40^{\circ} \mathrm{C}$ and maintained for $30 \mathrm{~min}$. Upon completion of reaction, the solvent was distilled off to get the crude. To the crude, water $(10 \mathrm{~mL})$ and ethyl acetate $(50 \mathrm{~mL})$ were added and stirred for $30 \mathrm{~min}$. The organic layer was separated and washed with brine solution $(5 \mathrm{~mL})$. The organic layer was dried over $\mathrm{Na}_{2} \mathrm{SO}_{4}$ and the solvent was distilled off to get the solid. Yield: $(83.5 \%)$; mp $152.8-154.9^{\circ} \mathrm{C}$; IR
$(\mathrm{KBr}): 1745.65(-\mathrm{C}=\mathrm{O}), 3334.10\left(-\mathrm{NHCH}_{3}\right)\left(\mathrm{cm}^{-1}\right)$. ${ }^{1} \mathrm{H}-\mathrm{NMR}\left(400 \mathrm{MHz}, \mathrm{CDCl}_{3}\right): \delta 1.30-1.40\left(\mathrm{td}, 6 \mathrm{H}, J_{1}=\right.$ $\left.7.06, J_{2}=6.92 \mathrm{~Hz}\right), 3.07(\mathrm{~d}, 3 \mathrm{H}, J=5.04 \mathrm{~Hz}), 3.61$ $(\mathrm{q}, 2 \mathrm{H}), 3.78(\mathrm{q}, 2 \mathrm{H}), 7.60\left(\mathrm{dd}, 1 \mathrm{H}, J_{1}=8.86, J_{2}=\right.$ $1.28 \mathrm{~Hz}), 7.82(\mathrm{~m}, 2 \mathrm{H}), 8.10(\mathrm{~d}, 1 \mathrm{H}, J=4.2 \mathrm{~Hz}), 8.45$ $(\mathrm{d}, 1 \mathrm{H}, J=1.0 \mathrm{~Hz}), 8.60(\mathrm{~d}, 1 \mathrm{H}, J=1.52 \mathrm{~Hz}), 8.65$ (d, $1 \mathrm{H}, J=8.32 \mathrm{~Hz}) ;{ }^{13} \mathrm{C}-\mathrm{NMR}\left(400 \mathrm{MHz}, \mathrm{CDCl}_{3}\right)$ : $\delta$ 12.76, 14.68, 26.14, 41.11, 43.34, 112.08, 112.86, $117.08,117.10,126.12,127.86,131.72,137.64$, $142.07,147.60,149.65,151.85,161.61,164.0 ; \mathrm{ms}: \mathrm{m} / \mathrm{z}$ $430.2(\mathrm{M})^{+}, 432.2(\mathrm{M})^{+2}, 433(\mathrm{M})^{+3}$. Anal. Calcd. for $\mathrm{C}_{19} \mathrm{H}_{20} \mathrm{BrN}_{5} \mathrm{O}_{2}: \mathrm{C}, 53.03 ; \mathrm{H}, 4.68 ; \mathrm{N}, 16.28$. Found $\mathrm{C}$, $53.01 ; \mathrm{H}, 4.69 ; \mathrm{N}, 16.29$.

\section{Biological evalution of newly synthesized compounds}

\subsection{AKT kinase inhibition assay}

The kinase inhibition assay was performed using Akt kinase assay kit from Cell Signalling Technologies, USA, according to manufacturer's protocol. Akt kinase was immunoprecipitated with Anti-AKT antibody provided in the kit from K562, chronic myelogenous leukaemia, cells. Inhibitory studies of the compounds on AKT kinase was performed at a final concentration of $10 \mu \mathrm{M}$ (dissolved in DMSO) in duplicates in presence of GSK- $\beta$ as the substrate for AKT. The enzyme activity was monitored by reading absorbance at $450 \mathrm{~nm}$ using TMB as the substrate for the HRPtagged secondary antibody. The \% activity was determined as a fraction of control (only DMSO).

\section{Results and discussion}

\subsection{Chemistry}

We herein report a general and novel synthesis of $1 H$-pyridin-4yl-3,5-disubstituted indazoles via Suzuki coupling in good yields. The synthesis starts

Table 1. Screening of Pd catalyst and base for Suzuki coupling reaction.

\begin{tabular}{lccc}
\hline Sl.no & $\mathrm{Pd}(\mathrm{cat}) /$ base/solvent & $\mathrm{Temp}\left({ }^{\circ} \mathrm{C}\right)$ & Yield (\%) \\
\hline 1 & $\mathrm{Pd}\left(\mathrm{pph}_{3}\right)_{4} / \mathrm{Na}_{2} \mathrm{CO}_{3} / \mathrm{DMF}$ & $95-100$ & 86 \\
2 & $\mathrm{PdCl}{ }_{2}(\mathrm{dppf}) / \mathrm{Na}_{2} \mathrm{CO}_{3}$ & $95-100$ & 60 \\
3 & $\mathrm{Pd}(\mathrm{OAc})_{2} / \mathrm{Na}_{2} \mathrm{CO}_{3} / \mathrm{DMF}$ & $85-100$ & 85 \\
4 & $\mathrm{Pd}(\mathrm{OAc})_{2} / \mathrm{CsF} / \mathrm{DMF}$ & $95-100$ & 92 \\
\hline
\end{tabular}


Table 2. Synthesis of 5-arylsubstituted-1-(2-cyanopyridin-4-yl)- $N, N$-diethyl- $1 H$ inda-zole-3-carboxamide (7a-f) by Suzuki coupling.

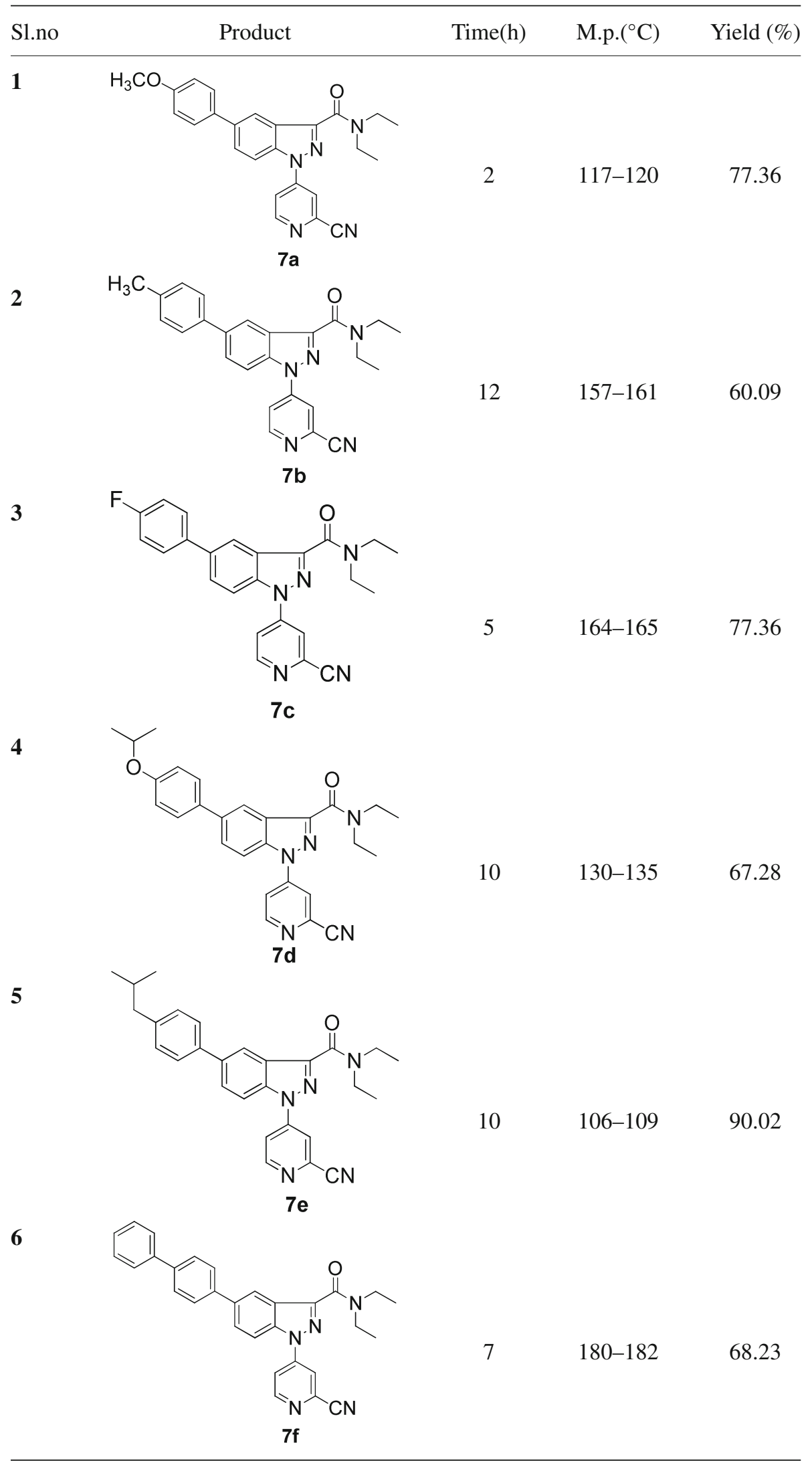


from 5-bromo-1-(2-cyano-pyridin-4-yl)- $1 H$-indazole3-carboxylic acid diethylamide $\mathbf{5}$, which is prepared according to our own procedure. ${ }^{13}$

The reaction of 5-bromo-1-(2-cyano-pyridin-4-yl)$1 H$-indazole-3-carboxylic acid diethylamide 5 with aryl boronic acids 6(a-f) through Suzuki reaction in the presence of different bases $\left(\mathrm{CsF} / \mathrm{Na}_{2} \mathrm{CO}_{3}\right)$ and different $\mathrm{Pd}$ catalysts such as $\mathrm{Pd}\left(\mathrm{pph}_{3}\right)_{4}$ or $\mathrm{Pd}(\mathrm{dppf}) \mathrm{Cl}_{2}$ or $\mathrm{Pd}(\mathrm{OAc})_{2}$ gave 5-arylsubstituted-1-(2-cyanopyridin4-yl)- $N, N$-diethyl- $1 H$-indazole-3-carboxamides $7(\mathbf{a}-\mathbf{f})$ in good yields. The best conditions were observed in the presence of $\mathrm{Pd}(\mathrm{OAc})_{2}$ and $\mathrm{CsF}$ (see table 1) and the results are tabulated in table 2. Later 7(a-f) was converted into 5-arylsubstituted-methyl 4-(3-(diethylcarbamoyl)-1H-indazol-1-yl) picolinate $8(\mathbf{a}-\mathbf{f})$ in presence of thionyl chloride and methanol

Table 3. Synthesis of 5-arylsubstituted- $N, N$-diethyl-1-(2-(methylcarbamoyl)pyridin4-yl)-1H-indazole-3-carboxamides $\mathbf{9}(\mathbf{a}, \mathbf{b}, \mathbf{c}, \mathbf{e}, \mathbf{f})$.

(\%)


<smiles></smiles>

5<smiles>[R]c1ccc(-c2ccc(N(C)C(=O)C(=O)N(CC)CC)c(-c3ccnc(C(=O)OC)c3)c2)cc1</smiles>

8<smiles>[R]O[Bi]c1ccc([18OH])cc1</smiles>

6<smiles>[R]c1ccc(-c2ccc(Nc3ccnc(C#N)c3)c(C(=N)C(=O)N(CC)CC)c2)cc1</smiles>

Mono methylamine

Methanol

$25-40^{\circ} \mathrm{C}$

$30 \mathrm{~min}$
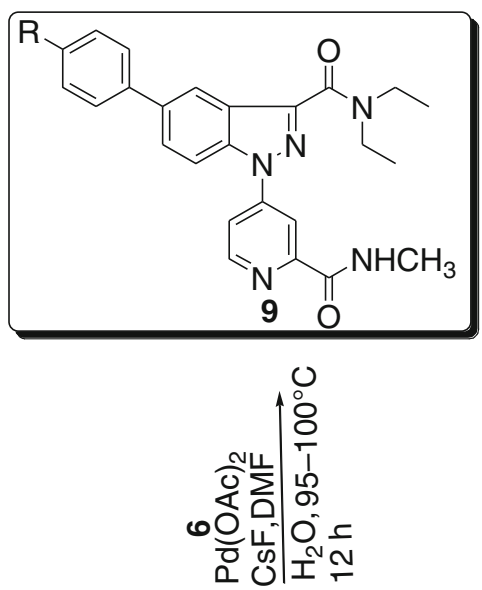

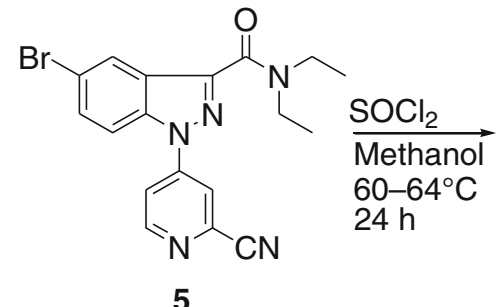

5<smiles>CCN(CC)C(=O)C(=N)c1cc(Br)ccc1Nc1ccnc(C(=O)OC)c1</smiles>
Mono methylamine<smiles>CCN(CC)C(=O)C(=N)c1cc(Br)c(C)cc1N</smiles>
Methanol $25-40^{\circ} \mathrm{C}$<smiles>CNC(=O)c1cc(I)ccn1</smiles><smiles>[R]OCC</smiles><smiles>Cc1ccccc1</smiles>

Scheme 1. Synthesis of 5-arylsubstituted-N,N-diethyl-1-(2-(methylcarbamoyl) pyridin-4-yl)-1Hindazole-3-carboxamide 9.

in $80-90 \%$ yields. Finally $\mathbf{8}(\mathbf{a}-\mathbf{f})$ was reacted with mono methylamine gas in methanol at $25-40^{\circ} \mathrm{C}$ to give the corresponding 5-arylsubstituted- $N, N$-diethyl1-(2-(methylcarbamoyl) pyridin-4-yl)-1H-indazole-3arboxamide $\mathbf{9}(\mathbf{a}-\mathbf{f})$ in good yields. These results are tabulated in table 3 and schematically represented in scheme 1.

Based on the successful results, we next explored the scope of the Suzuki reaction to synthesize 5arylsubstituted- $N, N$-diethyl-1-(2-(methylcarbamoyl) pyridin-4-yl)- $1 H$-indazole-3-carboxamides 9 from 5bromo-1-(2-cyano-pyridin-4-yl)-1H-indazole-3-carboxylic acid diethylamide $\mathbf{5}$ in a different manner. The 5-arylsubstituted- $N, N$-diethyl-1-(2-(methylcarbamoyl) pyridin-4-yl)- $1 H$-indazole-3-carboxamides were synthesized by initial conversion of nitrile 5 to methyl ester 10. Later, compound $\mathbf{1 0}$ was reacted with aryl boronic acids 6 in the presence of $\mathrm{Pd}\left(\mathrm{pph}_{3}\right)_{4} / \mathrm{Na}_{2} \mathrm{CO}_{3}$; $\mathrm{Pd}(\mathrm{OAc})_{2} / \mathrm{CsF}$ to give the corresponding coupling

Table 4. AKT kinase inhibitory concentration $(10 \mu \mathrm{M})$ against chronic myelogenous leukaemia cell line (K562).

\begin{tabular}{lc}
\hline Compound & \% Inhibition \\
\hline $\mathbf{7 a}$ & 24.04 \\
$\mathbf{7 b}$ & NA \\
$\mathbf{7 c}$ & NA \\
$\mathbf{7 d}$ & NA \\
$\mathbf{7 f}$ & 20.0 \\
$\mathbf{9 a}$ & 20.81 \\
$\mathbf{9 b}$ & 18.0 \\
$\mathbf{9 c}$ & 19.0 \\
$\mathbf{9 e}$ & NA \\
$\mathbf{9 f}$ & NA \\
$\mathbf{1 0}$ & 24.52 \\
\hline
\end{tabular}


products in moderate to good yields (40-60\%) (scheme 1).

\subsection{Biological activity}

The Akt inhibition efficiency of the newly synthesized compounds has been assessed using Akt activity assay kit. Results of the assay demonstrated a maximum of $24 \%$ inhibition by compounds $\mathbf{7 a}$ and $\mathbf{1 0}$ (table 4). Further, structure activity studies on compounds 7f, 9a, 9b and 9c might help in improving the Akt kinase inhibitory activity.

\section{Conclusion}

We have synthesized 5-arylsubstituted- $N, N$-diethyl-1(2-methylcarbamoyl)pyridine-4-yl)- $1 H$-indazole-3carboxamides and found that only 7a, 7f, 9a, 9b, 9c and $\mathbf{1 0}$ exhibit moderate inhibition. Further studies are necessary to obtain better Akt kinase inhibitory activity.

\section{Supplementary Information}

The electronic supplementary information can be seen at www.ias.ac.in/chemsci.

\section{Acknowledgement}

The authors thank the management of Suven Life Sciences for allowing us to publish these results.

\section{References}

1. Prieto M, Zurita E, Rosa E, Munoz L, Lioyd-Williams $\mathrm{P}$ and Giralt E 2004 J. Org. Chem. 696812

2. Migliorini A, Oliviero C, Gasperi $\mathrm{T}$ and Loreto $\mathrm{M} \mathrm{A}$ 2012 Molecule 174508

3. George I G, Tash J S, Ramappa Ch, Sudhakara Rao J and Calvet J P 2009 US Patent 20090197911

4. Rodgers J D, Johnson B L, Wang H, Erickson-Viitanen S, Klabe R M, Bacheler L, Cordova B C and Chang C H 1998 Bioorg. Med. Chem. Lett. 8715

5. Li W, Zhai X, Ding Lu, Sun L, Chen X, Gong P and Sun T 2011 Molecule 165130

6. Woods K W, Fisher J P, Claiborne A, Li T, Thomas S A, Zhu G, Diebold R B, Liu X, Shi Y and Klinghofer V 2006 Bioorg. Med. Chem. Lett. 146832

7. Akritopoulou-Zanze I, Wakefield B D, Mack H, Turner S C, Gasiecki A F, Gracias V J, Sarris K A, Kalvin D M, Michmerhuizen M J, Shuai Q, Patel J R, Bakker M H M, Teusch N, Johnson E F, Kovar P J, Djuric S W, Long A J, Vasudevan A, George D, Wang L, St. John Moore B, Li N, Hobson A D, Woods K W, Miyashiro J M, Swann S L and Jr. Penning T D 2009 US Patent 20090203690

8. Demers B and Vrignaud P 2012 US Patent 20120108641

9. Markus B, Jan D, Anders E, Balint G, Thomas H, Martin H, Krister H, Svetlana I, Matti L, Darren M, Magnus M A R, Stinabritt N, Hartmut R and Camilla T 2008 WO Patent 2008076048

10. Susan E K, Indrawan J M and Siegfried H R 2005 US Patent 2005026960.

11. (a) Veera Reddy A, Surendra Reddy G and Dubey P K 2012 J. Heterocycl. Chem. (in press); (b) Veera Reddy A, Surendra Reddy G and Dubey P K 2013 Syn. Commun. 432236

12. Veera Reddy A, Surendra Reddy G and Dubey P K 2011 J. Heterocycl. Chem. 48961

13. Veera Reddy A, Surendra Reddy G, Dubey P K, Madhava Reddy B and Veeresh B 2013 Synthesis, anti-inflammatory and analgesic activity of 1-pyridin4-yl-1H-indazole-3-carboxylic acid and its derivatives (Communicated to Med. Chem. Res. 2013) 